\title{
Penerapan Metode Association Rule Dalam Menganalisa Data Penjualan Obat Mengunakan Algoritma FP-GROWTH (Studi Kasus Rumah Sakit Haji Medan)
}

\author{
Ibnu Rusydi \\ Universitas Dharmawangsa, Medan, Indonesia \\ Email: ibnurusydi@dharmawangsa.ac.id
}

\begin{abstract}
Abstrak
Data transaksi penjualan merupakan harta yang sangat berharga dalam proses bisnis. Tidak hanya digunakan untuk menghitung laba dan rugi, namun data transaksi dalam jumlah yang besar juga dapat digunakan untuk berbagai kepentingan untuk menghasilkan pengetahuan baru (knowledge) di dalam database transaksi. Cara yang dapat dilakukan untuk pengolahan data dan menghasilkan pengetahuan baru dari data tersebut adalah dengan menggunakan teknik data mining. Adapun teknik yang digunakan dalam hal ini adalah Algoritma FP-Growth. Struktur data yang digunakan adalah tree yang disebut dengan FP-Tree. Dengan menggunakan FP-Tree, Algoritma FP-growth dapat langsung mengekstrak frequent Itemset dari FP-Tree. Penelitian dilakukan dengan mengumpulkan data terkait dimana pada penelitian ini studi kasus di Apotek Rumah Sakit Haji Medan yang mana variablevariable yang diambil adalah data transaksi obat perhari. Hasil penelitian ini adalah berupa suatu pengetahuan baru dari data penjualan tersebut dengan mengimplementasikan Algoritma FP-Growth yang menggunakan konsep pembangunan FP-Tree dalam mencari Frequent Itemset yang berguna untuk kepentingan kemajuan pengelolaan di tempat studi kasus diambil.
\end{abstract}

Kata Kunci : Data Mining, Association Rules, Frequent Itemset, FP-Growth.

\begin{abstract}
Sales transaction data is a very valuable asset in business processes. Not only is it used to calculate profits and money, but large amounts of transaction data can also be used for various purposes to generate new knowledge (knowledge) in the transaction database. Ways that can be done for data processing and generate new knowledge from the data is to use data mining techniques. The technique used in this case is the FP-Growth Algorithm. The data structure used is a tree called FP-Tree. By using FP-Tree, FP-growth Algorithm can directly extract Itemset from FP-Tree. Research conducted by collecting data related to research in the case studio at Medan Haji Hospital Pharmacy where the variables taken are daily drug transaction data. The results of this study are part of the new knowledge of this sales data by applying the FP-Growth Algorithm that uses the concept of FP-Tree development in finding Frequent Itemset that is useful for the development of investment plans in the study areas taken.
\end{abstract}

Keywords: Data Mining, Association Rules, Frequent Itemset, FP-Growth. 


\section{Pendahuluan}

\subsection{Latar Belakang Masalah}

Data transaksi penjualan merupakan harta yang sangat berharga dalam proses bisnis. Tidak hanya digunakan untuk menghitung laba dan rugi, namun data transaksi dalam jumlah yang besar juga dapat digunakan untuk berbagai kepentingan untuk menghasilkan pengetahuan baru (knowledge) di dalam database transaksi.

Apotik Rumah Sakit Haji Medan salah satu Apotik yang melayani pendistribusian obat yang akan ditebus atau dibeli oleh pasien yang sedang berobat di Rumah Sakit tersebut. Apotik tersebut juga melayani pembelian konsumen yang tidak khusus berobat di Rumah Sakit. Rumah Sakit Haji Medan memiliki transaksi yang sangat banyak setiap harinya. Data transaksi di Apotik ini sebagaimana sama seperti di Apotik-apotik pada umumnya hanya dipergunakan untuk mengetahui laba, rugi dan stok persediaan barang saja.

Berdasarkan Hal diatas maka penulis akan meneliti data-data transaksi penjualan yang ada dirumah sakit tersebut untuk menghasilkan pengetahuan baru yaitu berupa pola-pola transaksi yang saling berkaitan. Melalui data-data transaksi tersebut akan dicari berbagai informasi tentang kebiasaan para pasien/konsumen dalam bertransaksi, misalnya dapat diketahui produk-produk apa saja yang sering ditebus/dibeli secara bersamaan dalam tiap transaksi. Dengan adanya pengetahuan tersebut maka Apotik Rumah Sakit Haji Medan akan lebih optimal dalam meningkatkan transaksi penjualan, memaksimalkan pelayanan kepada konsumen, tetap tersedianya berbagai jenis obat dan manajemen penyimpanan di gudang yang efektif. Sebagai contoh menemukan bahwa produk A biasanya dibeli secara bersamaan dengan produk $\mathrm{B}$, maka pengetahuan ini akan memberikan input atau masukan ketika Apotik akan menambah persediaan kembali. Dan juga bermanfaat ketika menyusun barang di Gudang penyimpanan, maka Produk A dapat disusun berdekatan dengan Produk B untuk memudahkan ketika pencarian.

Permasalahan yang akan dibahas dalam hal ini yaitu penerapan metode Association Rule dengan Algoritma FP-Growth dapat diterapkan dalam pengelolaan data transaksi penjualan obat dan bagaimana pola hubungan aturan assosiatif antara suatu kombinasi item dan membentuk pola kombinasi itemsets dengan menggunakan Algoritma FP-Growth.

\section{Kajian Literatur Dan Pengembangan Hipotesis}

\subsection{Knowledge Discovery in Databases (KDD)}

Knowledge Discovery in Database (KDD) adalah keseluruhan proses non-trivial untuk mencari dan mengidentifikasi pola (pattern) dalam data, dimana pola yang ditemukan bersifat sah, baru, dapat bermanfaat dan dapat dimengerti. Data Mining sering dianggap sebagai bagian dari knowledge discovery in database (KDD) yaitu sebuah proses mencari pengetahuan yang bermanfaat dari data (Ali, et al 2015 ).

\subsection{Data Mining}

Kennedi, et al (2013) Data Mining disebut juga Knowledge Discovery in Database (KDD) didefenisikan sebagai ekstraksi informasi potensial, implisit dan tidak dikenal dari sekumpulan data. Proses Knowlegde Discovery in Database melibatkan hasil proses Data Mining (proses pengekstrak kecenderungan suatu pola data), kemudian mengubah hasilnya secara akurat menjadi informasi yang mudah dipahami.

\subsection{Association Rule}

Association Rule adalah teknik Data Mining untuk menemukan aturan assosiatif antara suatu kombinasi item. Algoritma aturan asosiasi akan menggunakan data latihan, sesuai dengan pengertian data mining, untuk menghasilkan pengetahuan. Pengetahuan apakah yang hendak dihasilkan dalam aturan asosiasi. Pengetahuan untuk mengetahuan item-item belanja yang sering dibeli secara bersamaan dalam suatu waktu. Aturan asosiasi yang berbentuk "if...then..." atau "jika...maka..." merupakan pengetahuan yang dihasilkan dari fungsi aturan asosiasi Fadlina (2014).

\subsection{FP-Growth}

FP-Growth adalah salah satu alternatif algoritma yang dapat digunakan untuk menentukan himpunan data yang paling sering muncul (frequent item set) dalam sekumpulan data. Algoritma FPGrowth merupakan pengembangan dari algoritma Apriori Ririanti (2014). 
Dalam pencarian frequent itemset, Algoritma FP-Growth menggunakan konsep pembangunan tree bukan membangkitkan semua kemungkinan kombinasi item sehingga memiliki waktu kompilasi yang lebih cepat. Struktur data tree yang digunakan algoritma $\mathrm{FP}$-Growth disebut dengan $\mathrm{FP}$-tree.

\section{Metode Penelitian}

Dalam metodologi penelitian ada urutan kerangka kerja yang harus diikuti, urutan kerangka kerja ini adalah gambaran dari langkah-langkah yang harus dilalui agar penelitian ini bisa berjalan dengan baik serta sesuai yang diharapkan. Kerangka kerja yang harus diikuti bisa dilihat pada gambar 3.1:

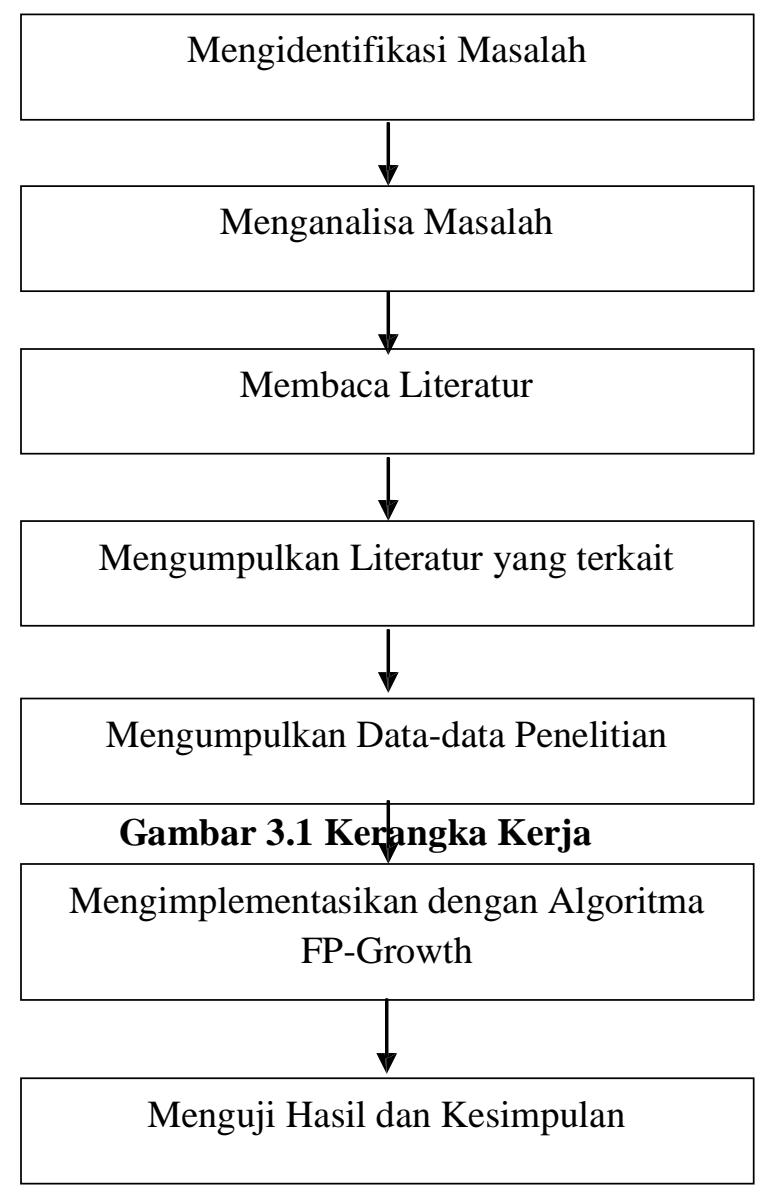

4. Hasil dan Pembahasan

Frequent Pattern Growth (FP-Growth) adalah salah satu alternatif algoritma yang dapat digunakan untuk menentukan himpunan data yang paling sering muncul (frequent itemset) dalam sebuah kumpulan data. Pada Algoritma Apriori diperlukan generate candidate untuk mendapatkan frequent itemsets. Akan tetapi, di Algoritma FP-Growth generate candidate tidak dilakukan karena FP-Growth menggunakan konsep pembangunan tree dalam pencarian frequent itemsets. Hal tersebutlah yang menyebabkan algoritma FP-Growth lebih cepat dari algoritma Apriori (Erwin, 2009).

Karakteristik algoritma FP-Growth adalah struktur data yang digunakan adalah tree yang disebut dengan FP-Tree. Dengan menggunakan FP-Tree, algoritma FP-growth dapat langsung mengekstrak frequent Itemset dari FP-Tree. Penggalian itemset yang frequent dengan menggunakan algoritma $F P$ Growth akan dilakukan dengan cara membangkitkan struktur data tree atau disebut dengan FPTree. Metode FP-Growth dapat dibagi menjadi 3 tahapan utama yaitu sebagai :

1. Tahap pembangkitan conditional pattern base,

2. Tahap pembangkitan conditional FP-Tree, dan

3. Tahap pencarian frequent itemset. 
Penelitian ini menggunakan proses asosiasi dalam menganalisa penjualan obat yang akan diproses dengan pembangunan FP-tree dalam pencarian frequent itemsets untuk menghasilkan suatu output. Data data tersebut mempunyai beberapa kriteria yang merupakan syarat dalam pembangunan $F P$-tree. Kumpulan frequent itemsets dicari dengan melakukan scanning database kemudian hasilnya diakumulasikan dengan tiap items lainnya dan dikelompokkan untuk mendapatkan frequent itemsets yang memenuhi nilai minimum support. Setelah didapatkan frequent itemsets, lalu frequent itemsets yang memiliki nilai kurang dari minimum support akan dipangkas atau dibuang. Sehingga akan didapatkan frequent itemsets yang memenuhi minimum support dan disusun dengan urutan menurun.

Untuk melakukan proses asosiasi dalam menganalisa data penjualan tersebut, sampel data yang digunakan adalah data transaksi penjualan obat di Apotek Rumah Sakit Haji selama satu tahun terakhir.

\subsection{Pemilihan Variabel}

Data sampel yang diuji dalam penelitian ini sebanyak 30 transaksi data penjualan obat, format seperti berikut :

1. ID Transaksi

2. Product Code

3. Product

4. Product Group

Adapun yang diambil sebagai variabel dalam asosiasi adalah mengenai Id Transaksi, Product code, Product, Product Group dan empat variabel ini akan dijadikan acuan untuk membentuk algoritma FP-Growth dibagi menjadi tiga langkah utama, namun terlebih dahulu dilakukan pembentukan pohon dengan menggunakan algoritma FP-Tree. Frequent Patern Tree (FP-Tree) adalah representasi pemasukan data yang dipadatkan.

Tabel 4.1 Data Penjualan Obat

\begin{tabular}{|l|l|l|l|}
\hline \multicolumn{1}{|c|}{ ID Transaksi } & Product Code & \multicolumn{1}{|c|}{ Product } & Product Group \\
\hline 253140 & ATU1 & Atracurium Hameln 25 & Atracurium \\
\hline 253140 & CDX2 & Cytodrox 500Mg Box / 10 Str & Cytodrox \\
\hline 253140 & CET4 & Ceteron 4Mg / Box 2 Str @ 6 Cp & Ceteron \\
\hline 253140 & DNM2 & Denomix Cream 10 Gr/Tube & Denomix \\
\hline 253140 & DXR2 & Doxorubin Inj 50 Mg 25 Ml/Vial & Doxorubin \\
\hline 253140 & FLT9 & Fleet Enema & Fleet \\
\hline 253140 & FSC1 & Fusycom Cream 5G/Tube & Fusycom \\
\hline 253140 & MPD1 & Mepirilid 1 Mg 30 Tab/Box & Mepirilid \\
\hline 253140 & NPN1 & Nopantin 300Mg 30Caps/Box & Nopantin \\
\hline 253140 & NSG1 & Neostigmine-Hameln 05Mg/Ml & Neostigmine \\
\hline 253140 & PFC1 & Profecom 100 Mg Box 10 Supp & Profecom \\
\hline 253140 & PSY1 & Posyd Inj 100 Mg & Posyd \\
\hline
\end{tabular}


ALGORITMA: Jurnal Ilmu Komputer dan Informatika

Volume: 03, Number: 02, November 2019 ISSN 2598-6341 (online)

\begin{tabular}{|l|l|l|l|}
253140 & USF3 & Ulsafate Suspensi 100 Ml & Ulsafate \\
\hline 253140 & VGT1 & Vagistin Ovula / Box 10S & Vagistin \\
\hline 244422 & CDX2 & Cytodrox 500Mg Box / 10 Str & Cytodrox \\
\hline 244422 & CET4 & Ceteron 4Mg / Box 2 Str @ 6 Cp & Ceteron \\
\hline 244422 & FSC1 & Fusycom Cream 5G/Tube & Fusycom \\
\hline 220621 & ATU2 & Atracurium Hameln 50 & Atracurium \\
\hline 220621 & BNM1 & Blenamax Inj. 15 I.U./10 Ml & Blenamax \\
\hline 220621 & CBS2 & Carbosin Inj Rtus 150 Mg/Vial & Carbosin \\
\hline 220621 & CBS4 & Carbosin Inj 450 Mg / 45 Ml & Carbosin \\
\hline 220621 & CDX2 & Cytodrox 500Mg Box / 10 Str & Cytodrox \\
\hline
\end{tabular}

Tabel 4.1 Data Penjualan Obat (lanjutan)

\begin{tabular}{|c|c|c|c|}
\hline ID Transaksi & Product Code & Product & Product Group \\
\hline 220621 & DXR1 & Doxorubin Inj $10 \mathrm{Mg}$ 5Ml/Vial & Doxorubin \\
\hline 220621 & DXR2 & Doxorubin Inj $50 \mathrm{Mg} 25 \mathrm{Ml} / \mathrm{Vial}$ & Doxorubin \\
\hline 220621 & ETX3 & Emthexate Injection $5 \mathrm{Mg} / \mathrm{Vial}$ & Emthexate \\
\hline 220621 & ETX4 & Emthexate Injection $50 \mathrm{Mg} / \mathrm{Vial}$ & Emthexate \\
\hline 220621 & FLT9 & Fleet Enema & Fleet \\
\hline 220621 & FRC2 & Fluracedyl Inj.Vial 500Mg/10Ml & Fluracedyl \\
\hline \multicolumn{4}{|c|}{ sampai dengan transaksi ke 30: } \\
\hline 219519 & PTS2 & Platosin Inj Rtus 50 Mg/Vial & Platosin \\
\hline 219519 & $\mathrm{RCV} 4$ & Rescuvolin Inj 50 Mg/10 Ml & Rescuvolin \\
\hline 219519 & VCT1 & Vincristine Sulf Inj 1Mg/1Ml & Vincristine \\
\hline
\end{tabular}




\subsection{Pra-Proses}

Berdasarkan variabel-variabel yang sudah terpilih, format data menjadi seperti tampak pada tabel 4.2 di bawah ini :

Tabel 4.2 Pembentukan Setelah Pemilihan Variabel

\begin{tabular}{|l|l|l|}
\hline TID & ID Transaksi & \multicolumn{1}{c|}{ Product Group } \\
\hline \multirow{2}{*}{1} & \multirow{2}{*}{253140} & Atracurium \\
\cline { 2 - 3 } & & Cytodrox \\
& & Ceteron \\
& & Denomix \\
& & Doxorubin \\
\hline
\end{tabular}

Tabel 4.2 Pembentukan Setelah Pemilihan Variabel (Lanjutan)

\begin{tabular}{|c|c|c|}
\hline TID & ID Transaksi & Product Group \\
\hline & & Fleet \\
\hline & & Fusycom \\
\hline & & Mepirilid \\
\hline & & Nopantin \\
\hline & & Neostigmine \\
\hline & & Profecom \\
\hline & & Posyd \\
\hline & & Ulsafate \\
\hline & & Vagistin \\
\hline \multirow{3}{*}{2} & \multirow{3}{*}{244422} & Cytodrox \\
\hline & & Ceteron \\
\hline & & Fusycom \\
\hline \multirow{7}{*}{3} & \multirow{7}{*}{220621} & Atracurium \\
\hline & & Blenamax \\
\hline & & Carbosin \\
\hline & & Cytodrox \\
\hline & & Doxorubin \\
\hline & & Emthexate \\
\hline & & Fleet \\
\hline
\end{tabular}




\begin{tabular}{|c|c|c|}
\hline & & Fluracedyl \\
\hline & & Fusycom \\
\hline & & Neostigmine \\
\hline & & Phental \\
\hline & & Posyd \\
\hline & & Platosin \\
\hline & & Rescuvolin \\
\hline & & Vinblastine \\
\hline 4 & 251477 & Cytodrox \\
\hline & & Fleet \\
\hline Sampai denga & & \\
\hline & & Platosin \\
\hline 30 & & Rescuvolin \\
\hline & & Vincristine \\
\hline
\end{tabular}

Langkah selanjutnya adalah membuat simbol atau pengkodean dari nama-nama produk, dan sekaligus penghitungan frekuensi dan nilai support. Selanjutnya untuk Mencari Frequent itemset, maka diambil dari nilai frequency yang paling sering muncul, dan dalam penelitian ini penulis menentukan minimum supportnya adalah $20 \%$.

$=\frac{20 * 30}{100}=6$

Tabel 4.3 Frekuensi Itemset

\begin{tabular}{|l|c|c|c|c|}
\hline \multicolumn{1}{|c|}{ Product Group } & Simbol Itemset & Frekuensi & \multicolumn{2}{c|}{ Support } \\
\hline Atracurium & $\mathrm{A}$ & 5 & $5 / 30$ & $16,66 \%$ \\
\hline Blenamax & $\mathrm{B}$ & 1 & $1 / 30$ & $3 \%$ \\
\hline Carbosin & $\mathrm{C}$ & 4 & $4 / 30$ & $13,33 \%$ \\
\hline Ceteron & $\mathrm{D}$ & 4 & $4 / 30$ & $13,33 \%$ \\
\hline Comdipin & $\mathrm{E}$ & 2 & $2 / 30$ & $6,67 \%$ \\
\hline Cytodrox & $\mathrm{F}$ & 8 & $8 / 30$ & $26,67 \%$ \\
\hline Denomix & $\mathrm{G}$ & 2 & $2 / 30$ & $6,67 \%$ \\
\hline Dobutamin & $\mathrm{H}$ & 1 & $1 / 30$ & $3 \%$ \\
\hline Doxorubin & $\mathrm{I}$ & 3 & $3 / 30$ & $10 \%$ \\
\hline Emthexate & $\mathrm{J}$ & 1 & $1 / 30$ & $3 \%$ \\
\hline Fleet & $\mathrm{K}$ & 8 & $8 / 30$ & $26,67 \%$ \\
\hline Fluracedyl & $\mathrm{L}$ & 3 & $3 / 30$ & $10 \%$ \\
\hline Fusycom & $\mathrm{M}$ & 14 & $14 / 30$ & $46,67 \%$ \\
\hline Mepirilid & $\mathrm{N}$ & 4 & $4 / 30$ & $13 \%$ \\
\hline Neostigmine & $\mathrm{O}$ & 7 & $7 / 30$ & $23,33 \%$ \\
\hline Nopantin & $\mathrm{P}$ & 2 & $2 / 30$ & $6,67 \%$ \\
\hline Phental & $\mathrm{Q}$ & 1 & $1 / 30$ & $3 \%$ \\
\hline Platosin & $\mathrm{R}$ & 2 & $2 / 30$ & $6,67 \%$ \\
\hline Posyd & $\mathrm{S}$ & 3 & $3 / 30$ & $10 \%$ \\
\hline Profecom & $\mathrm{T}$ & 2 & $2 / 30$ & $6,67 \%$ \\
\hline Rescuvolin & $\mathrm{U}$ & 2 & $2 / 30$ & $6,67 \%$ \\
\hline Ulsafate & $\mathrm{V}$ & 17 & $17 / 30$ & $56,67 \%$ \\
\hline
\end{tabular}


ALGORITMA: Jurnal Ilmu Komputer dan Informatika

Volume: 03, Number: 02, November 2019 ISSN 2598-6341 (online)

\begin{tabular}{|l|c|c|c|c|}
\hline Vagistin & $\mathrm{W}$ & 6 & $6 / 30$ & $20 \%$ \\
\hline Vinblastine & $\mathrm{X}$ & 1 & $1 / 30$ & $3 \%$ \\
\hline Vincristine & $\mathrm{Y}$ & 1 & $1 / 30$ & $3 \%$ \\
\cline { 3 - 5 } & $\mathrm{Z}$ & & & \\
\hline
\end{tabular}

Setelah pencarian nilai support $20 \%$ maka hasil yang diambil seperti terlihat pada tabel diatas adalah frequency yang nilai minimumnya bernilai 6 dan diatasnya:

- $\quad$ Ulsafate ( V $)=17$

- $\operatorname{Fusycom}(\mathrm{M})=14$

- $\quad$ Cytodrox $(\mathrm{F})=8$

- $\quad$ Fleet $(\mathrm{K})=8$

- Neostigmine ( O $)=7$

- $\quad$ Vagistin $(\mathrm{W})=6$

Tabel 4.4 Frequent Itemset yang Terbentuk

\begin{tabular}{|c|c|}
\hline TID & ITEM \\
\hline 1 & $\mathrm{~V}, \mathrm{M}, \mathrm{F}, \mathrm{K}, \mathrm{O}, \mathrm{W}$ \\
\hline 2 & $\mathrm{M}, \mathrm{F}$ \\
\hline 3 & $\mathrm{M}, \mathrm{F}, \mathrm{K}, \mathrm{O}$ \\
\hline 4 & $\mathrm{~F}, \mathrm{~K}, \mathrm{~W}$ \\
\hline 5 & $\mathrm{~V}, \mathrm{M}, \mathrm{W}$ \\
\hline 6 & $\mathrm{~V}$ \\
\hline 7 & $\mathrm{~F}$ \\
\hline 8 & $\mathrm{~V}, \mathrm{M}, \mathrm{K}, \mathrm{W}$ \\
\hline 9 & $\mathrm{~F}$ \\
\hline 10 & $\mathrm{M}$ \\
\hline 11 & $\mathrm{M}$ \\
\hline 12 & $\mathrm{~V}, \mathrm{O}$ \\
\hline 13 & $\mathrm{~V}, \mathrm{O}$ \\
\hline 14 & $\mathrm{~K}$ \\
\hline 15 & $\mathrm{~V}$ \\
\hline 16 & $\mathrm{~V}, \mathrm{M}, \mathrm{K}, \mathrm{O}$ \\
\hline 17 & $\mathrm{~V}, \mathrm{M}$ \\
\hline 18 & $\mathrm{~V}, \mathrm{~F}, \mathrm{~W}$ \\
\hline 19 & $\mathrm{M}$ \\
\hline 20 & - \\
\hline 21 & - \\
\hline 22 & $\mathrm{~V}$ \\
\hline 23 & $\mathrm{~V}, \mathrm{M}, \mathrm{F}, \mathrm{K}$ \\
\hline 24 & $\mathrm{~V}, \mathrm{~W}$ \\
\hline 25 & $\mathrm{~V}, \mathrm{~K}$ \\
\hline 26 & $\mathrm{~V}, \mathrm{M}$ \\
\hline
\end{tabular}




\begin{tabular}{|c|c|}
27 & $\mathrm{O}$ \\
\hline 28 & $\mathrm{~V}$ \\
\hline 29 & $\mathrm{~V}, \mathrm{M}, \mathrm{O}$ \\
\hline 30 & $\mathrm{M}$ \\
\hline
\end{tabular}

Tabel 4.4 diatas menggambarkan Frequent Itemset yang terbentuk dari 30 transaksi berdasarkan pengkodean yang telah dibuat.

Langkah selanjutnya adalah membentuk pohon FP-Tree:

Gambar di bawah ini memberikan ilustrasi mengenai pembentukan FP-tree setelah pembacaan TID1

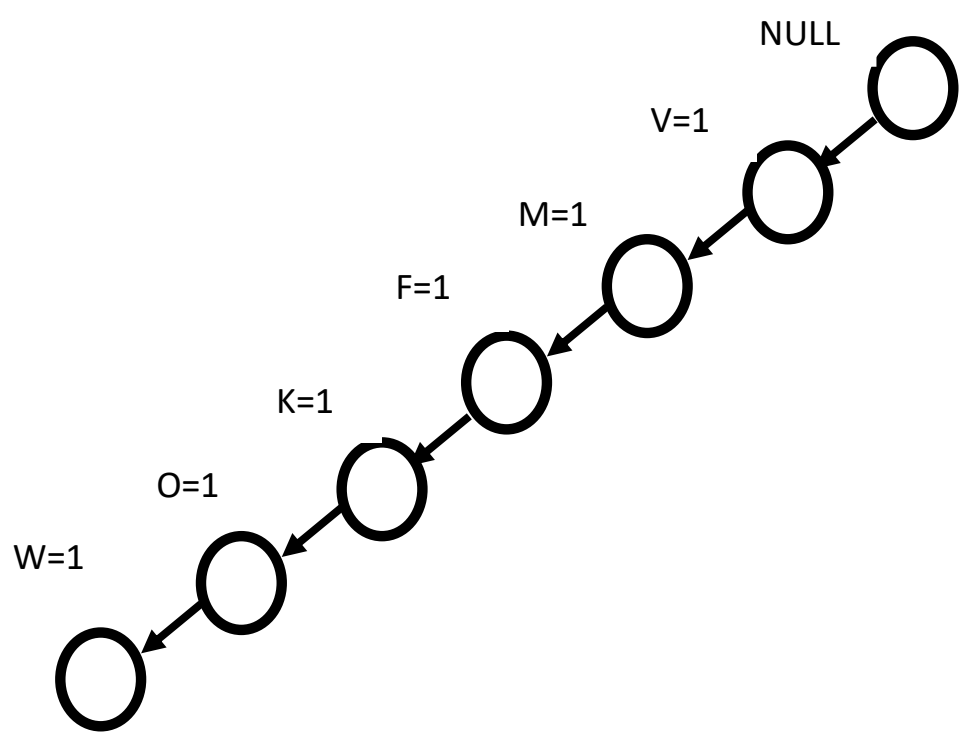

\section{Gambar 4.1: Hasil Pembentukan FP-tree Setelah}

Pembacaan TID 1

Gambar didapat setelah melakukan TID 1, Yaitu berisi : NULL V (Ulsafate)=1, M (Fusycom)=1, F $($ Cytodrox $)=1, \mathrm{~K}($ Fleet $)=1, \mathrm{O}($ Neostigmine $)=1, \mathrm{~W}($ Vagistin $)=1$

Selanjutnya pembentukan FP-tree untuk pembacaan TID 2:

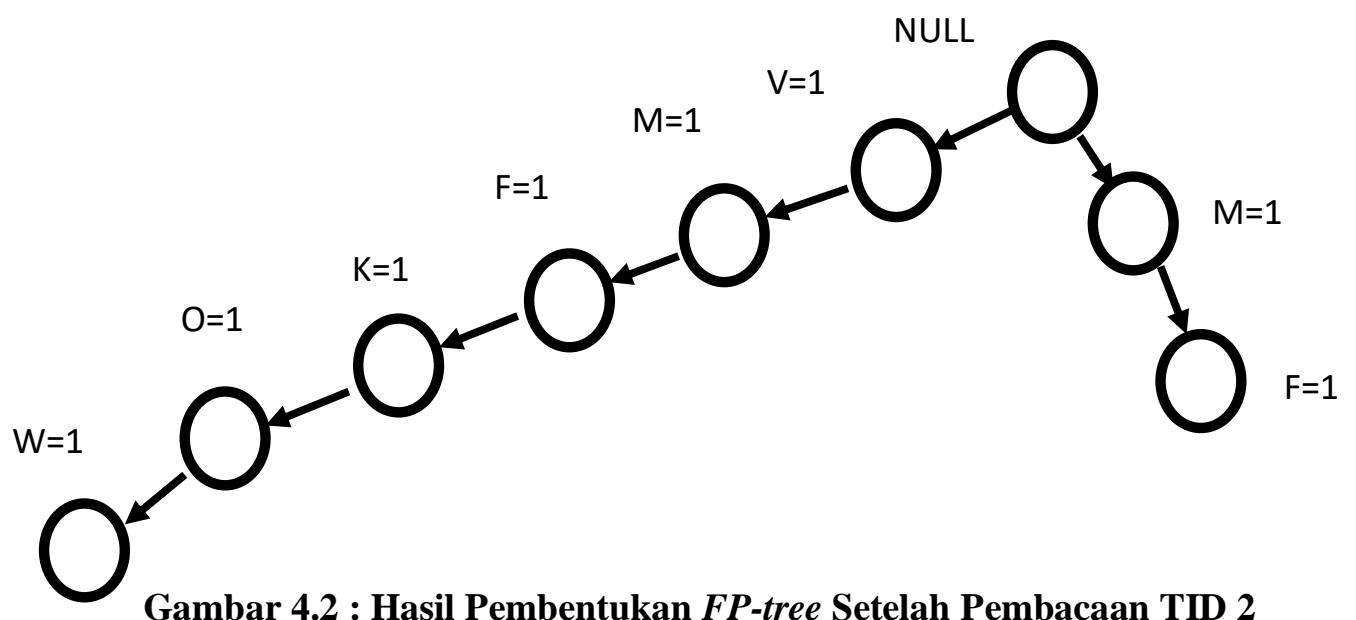


Gambar didapat setelah melakukan TID 2,Yaitu: NULL- M(Fusycom)=1, F(Cytodrox $)=1$ Selanjutnya pembentukan $F P$-tree untuk pembacaan TID 3:

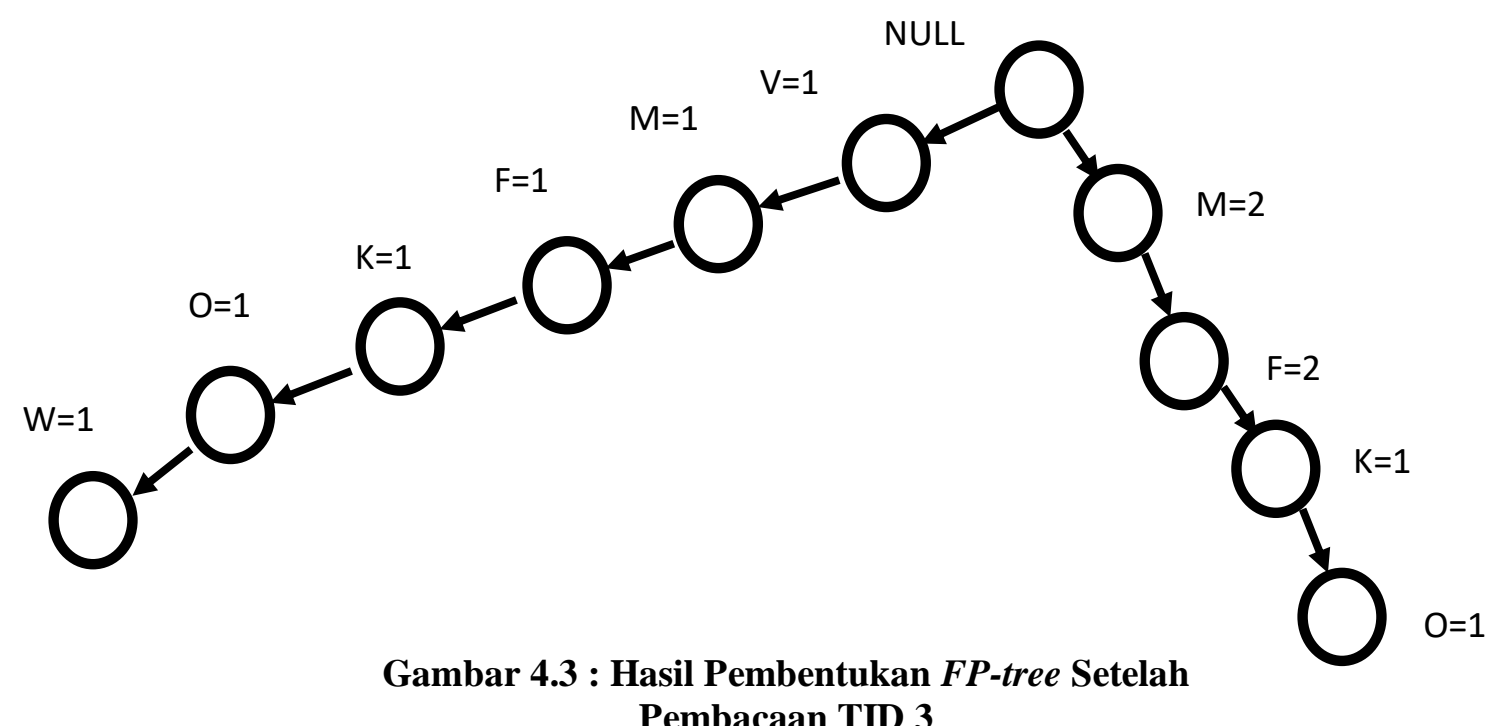

Begitu selanjutnya sampai pembentukan FP-tree untuk pembacaan TID 30:

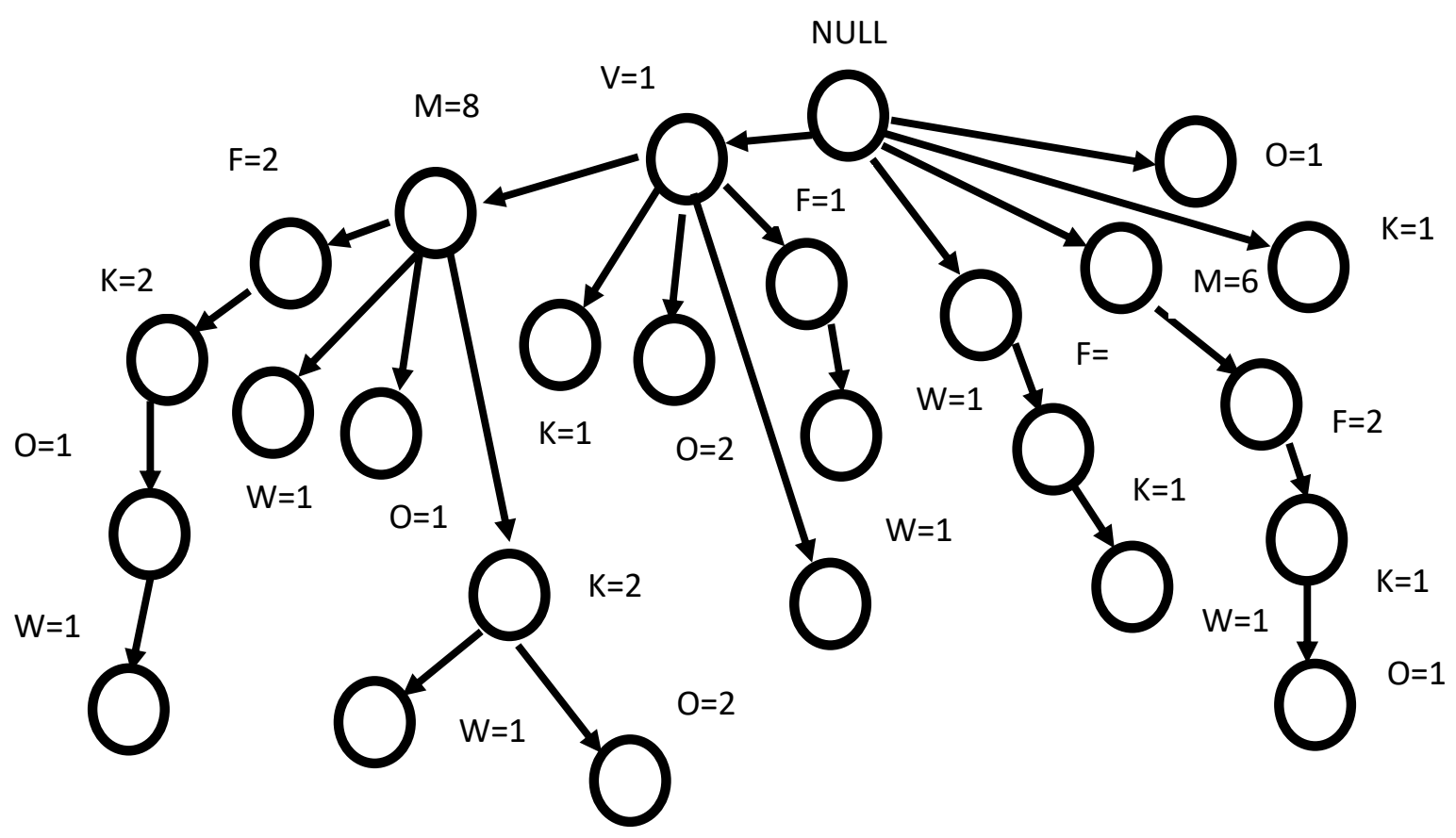

Gambar 4.4 : Hasil Pembentukan FP-tree Setelah Pembacaan TID 30

Gambar didapat setelah melakukan TID 30 yang dijumlahkan, yaitu berisi Null $\mathrm{V}($ Ulsafate $)=17, \mathrm{M}($ Fusycom $)=14, \mathrm{~F}($ Cytodrox $)=8, \mathrm{~K}($ Fleet $)=8, \mathrm{O}($ Neostigmine $)=7, \mathrm{~W}($ Vagistin $)=6$.

Setelah mencari frequent itemset untuk beberapa akhiran suffix maka didapat hasil yang dirangkum dalam tabel berikut: 


\begin{tabular}{|l|l|}
\hline \multicolumn{2}{|c|}{ Tabel 4.5 Daftar Frequent Itemset Diurutkan Berdasarkan Hubungan Akhiran } \\
\begin{tabular}{|l|l|}
\hline Suffix & Frequent Itemset \\
\hline W & $\{\{\mathrm{V}, \mathrm{M}, \mathrm{F}, \mathrm{K}, \mathrm{O}, \mathrm{W}\}\},\{\{\mathrm{V}, \mathrm{M}, \mathrm{K}, \mathrm{W}\}\},\{\{\mathrm{V}, \mathrm{M}, \mathrm{W}\}\},\{\{\mathrm{V}, \mathrm{F}, \mathrm{W}\}\},\{\{\mathrm{V}, \mathrm{W}\}\},\{\{\mathrm{F}, \mathrm{K}$, \\
$\mathrm{W}\}\}$.
\end{tabular} \\
\hline $\mathrm{O}$ & $\{\{\mathrm{V}, \mathrm{M}, \mathrm{F}, \mathrm{K}, \mathrm{O}\}\},\{\{\mathrm{V}, \mathrm{M}, \mathrm{K}, \mathrm{O}\}\},\{\{\mathrm{V}, \mathrm{M}, \mathrm{O}\}\},\{\{\mathrm{V}, \mathrm{O}\}\},\{\{\mathrm{M}, \mathrm{F}, \mathrm{K}, \mathrm{O}\}\}$. \\
\hline K & $\{\{\mathrm{V}, \mathrm{M}, \mathrm{F}, \mathrm{K}\}\},\{\{\mathrm{V}, \mathrm{M}, \mathrm{K}\}\},\{\{\mathrm{V}, \mathrm{K}\}\},\{\{\mathrm{M}, \mathrm{F}, \mathrm{K}\}\},\{\{\mathrm{F}, \mathrm{K}\}\},\{\{\mathrm{M}, \mathrm{K}\}\}$ \\
\hline $\mathrm{F}$ & $\{\{\mathrm{V}, \mathrm{M}, \mathrm{F}\}\},\{\{\mathrm{V}, \mathrm{F}\}\},\{\{\mathrm{M}, \mathrm{F}\}\}$. \\
\hline V & $\{\{\mathrm{V}, \mathrm{M}\}\}$. \\
\hline
\end{tabular}

Tahap selanjutnya adalah menghitung nilai support dan confidance dan memfilter itemset berdasarkan minimum support dan confidance dan selanjutnya menentukan aturan asosiasi dari nilai-nilai yang telah didapat:

Tabel 4.6 Aturan Asosiasi (Association Rule)

\begin{tabular}{|c|c|c|c|c|}
\hline No & Itemset & Qty & Support \% & Confidence \% \\
\hline 1 & V, M & 8 & 26,66 & 47,05 \\
\hline 2 & M, V & 8 & $26,66 \%$ & 57,14 \\
\hline 3 & V, F & 3 & 10 & 17,64 \\
\hline 4 & F, V & 3 & 10 & 37,50 \\
\hline 5 & V, K & 5 & 16,66 & 29,41 \\
\hline 6 & K, V & 5 & 16,66 & 62,50 \\
\hline 7 & V, O & 5 & 16,66 & 29,41 \\
\hline 8 & O, V & 5 & 16,66 & 71,42 \\
\hline 9 & V, W & 5 & 16,66 & 29,41 \\
\hline 10 & W, V & 5 & 16,66 & 83,33 \\
\hline 11 & M, K & 5 & 16,66 & 35,71 \\
\hline 12 & K, M & 5 & 16,66 & 62,50 \\
\hline 13 & M, F & 4 & 13,33 & 28,57 \\
\hline 14 & F, K & 4 & 13,33 & 50 \\
\hline 15 & V, M, F & 2 & 6,66 & 25 \\
\hline 16 & V, M, K & 4 & 13,33 & 50 \\
\hline 17 & V, M, O & 3 & 10 & 37,5 \\
\hline 18 & V, M, W & 3 & 10 & 37,5 \\
\hline 19 & V, F, W & 2 & 6,66 & 66,66 \\
\hline 20 & M, F, K & 3 & 10 & 75 \\
\hline 21 & F, K, W & 2 & 6,66 & 50 \\
\hline 22 & V, M, K, W & 2 & 6,66 & 50 \\
\hline 23 & V, M, K, O & 2 & 6,66 & 50 \\
\hline 24 & M, F, K, O & 2 & 6,66 & 100 \\
\hline 25 & V, M, F, K & 2 & 6,66 & 50 \\
\hline 26 & V, M, F, K, O & 1 & 3,33 & 100 \\
\hline 27 & V, M, F, K, O, W & 1 & 3,33 & \\
\hline & & & & \\
\hline
\end{tabular}

Setelah didapat aturan asosiasi seperti tabel diatas maka ditentukan besaran support dan confidence yang akan digunakan, Minimum support yang digunakan pada penelitian ini adalah $15 \%$ dan minimum confidence $25 \%$.

Berikut tabel setelah ditentukan minimum support dan confidance: 
Tabel 4.7 Aturan Asosiasi dengan Minimum Support dan Confidance

\begin{tabular}{|c|c|c|c|c|}
\hline No & Itemset & Qty & Support \% & Confidence \% \\
\hline 1 & V, M & 8 & 26,66 & 47,05 \\
\hline 2 & M, V & 8 & 26,66 & 57,14 \\
\hline 3 & V, K & 5 & 16,66 & 29,41 \\
\hline 4 & K, V & 5 & 16,66 & 62,50 \\
\hline 5 & V, O & 5 & 16,66 & 29,41 \\
\hline 6 & O, V & 5 & 16,66 & 71,42 \\
\hline 7 & V, W & 5 & 16,66 & 29,41 \\
\hline 8 & W, V & 5 & 16,66 & 83,33 \\
\hline 9 & M, K & 5 & 16,66 & 35,71 \\
\hline 10 & K, M & 5 & 16,66 & 62,50 \\
\hline
\end{tabular}

\section{Kesimpulan} berikut:

Dari tahap-tahap yang telah dilakukan di atas, maka dapat diambil kesimpulan sebagai

1. Jika membeli Ulsafate (V) maka akan membeli Fusycom (M) dengan support 26,66\% dan confidence $47,05 \%$.

2. Jika membeli Fusycom (M) maka akan membeli Ulsafate (V) dengan support 26,66\% dan confidence $57,14 \%$.

3. Jika membeli Ulsafate (V) akan membeli Fleet (K) dengan support 16,66\% dan confidence $29,41 \%$.

4. Jika membeli Fleet (K) akan membeli Ulsafate (V) dengan support 16,66\% dan confidence $62,50 \%$.

5. Jika membeli Ulsafate (V) maka akan membeli Neostigmine (O) dengan support $16,66 \%$ dan confidence $29,41 \%$.

6. Jika membeli Neostigmine (O) maka akan membeli Ulsafate (V) dengan support 16,66\% dan confidence $71,42 \%$.

7. Jika membeli Ulsafate (V) maka akan membeli Vagistin (W) dengan support 16,66\% dan confidence $29,41 \%$.

8. Jika membeli Vagistin (W) maka akan membeli Ulsafate (V) dengan support $16,66 \%$ dan confidence $83,33 \%$.

9. Jika membeli Fusycom (M) maka akan membeli Fleet (K) dengan support 16,66 \% dan confidence $35,71 \%$.

10. Jika membeli Fleet (K) maka akan membeli Fusycom (M) dengan support 16,66 \% dan confidence $35,71 \%$.

\section{DAFTAR REFERENSI}

1. Amira H. Shalaby, Dr.Mohmoud M.Abd el letif, Dr. Amira Rezk, Prof. Mohamed Hagag “ Suggested Marketing Strategy Using Apriori and FPGrowth Algorithms in retail sales in Egypt “ International Journal Of Computers \& Technology Vol. 14, no.11 Tahun 2015.

2. Donny MitraVirgiawan dan Imam Mukhlas "Aplikasi Association Rule Mining Untuk Menemukan Pola Pada Data Nilai Mahasiswa Matematika ITS ” Jurnal Sains, Surabaya, 2013. Eferi Buulolo “ Implementasi Algoritma Apriori Pada Sistem Persediaan Obat .” Medan, 2013.

3. Fadlina " Data Mining Untuk Analisa Tingkat Kejahatan Jalanan Dengan Algoritma Asociation Rule Metode Apriori."Vol 111 no 1 ,Sumatera Barat" 2014.

4. Goldie Gunadi dan Dana Indra Sensue " Penerapan Metode Data Mining Marbet Basket Analyis Terhadap Data Penjualan Produk Baru Dengan Menguunakan Algoritma Apriori dan Frequent Pattern Growth ( FP-Growth ).” Telematika Vol.4 No.1, 2012.

5. J. Suresh, P. Rushyanth, Ch. Trinath " Generating associations rule mining using Apriori and FPGrowth Algorithms " IJCTT volume 4 Issue 4, 2013. 
6. Kennedi Tampubolon, Hoga Saragih dan Boby Reza "Implementasi Data Mining Algoritma Apriori Pada Sistem Persediaan Alat-alat Kesehatan .” INTI Vol.1 No.1, Medan, 2013.

7. Rahma Novta Miraldi, Antonius Rahmat dan Budi Susanto "Implementasi Algoritma FP-Growth Untuk Sistem Rekomendasi Buku di Perpusatakaan UKDW."Vol.10 No.1, 2014.

8. Rakesh Kumar Soni, Prof. Neetesh Gupta, Prof. Amit Sinhal " An FP-Growth Aproach to Mining Association Rule ." IJCSMC Vol.2 , 2013. Ririanti “ Implementasi Algoritma FP-Growth Pada Aplikasi Prediksi Persediaan Sepeda Motor .” PIBD Vol.VI No.1, 2014 